\title{
Effects of the Integration of PhET Simulations in the Teaching and Learning of the Physical Sciences of Common Core (Morocco)
}

\author{
Cherif Alaoui Mrani ${ }^{1,2, *}$, Abdelkrim El hajjami ${ }^{1,2}$, Khalid El khattabi ${ }^{2}$ \\ ${ }^{1}$ Interdisciplinary Laboratory of Research in Didactics of Sciences and Technology (LIRDIST), Faculty of Sciences Dhar El Mahraz, \\ Sidi Mohammed Ben Abdellah University, B.P. 1796, Fez-Atlas 30003, Morocco \\ ${ }^{2}$ Laboratory of Computer and Interdisciplinary Physic (LIPI), ENS (Ecole Normale supérieure), Sidi Mohammed Ben Abdellah \\ University, B.P. 1796, Fez -Atlas 30003, Morocco
}

Received April 5, 2020; Revised May 20, 2020; Accepted June 4, 2020

Copyright $\odot 2020$ by authors, all rights reserved. Authors agree that this article remains permanently open access under the terms of the Creative Commons Attribution License 4.0 International License

\begin{abstract}
Since 2000 till nowadays, the Moroccan educational system is increasingly evolving towards the optimal adoption of the competency-based approach that focuses on the learner. From this perspective, it is necessary to search for new pedagogical tools that can emulate the real experiment in creating motivational learning environments and improving the process of acquiring competences, especially with the shortage of experimental equipment in school lab. With the growing interest in ICT (Information Communication Technology), the use of interactive simulations has emerged as a true competitor to the real experience, and an effective alternative to traditional practices. This work aims to study the impact of using the interactive simulation product "Buoyancy" created as part of the physics project Education Technology (PhET), on the understanding and learning of common core science students. A comparative study has been performed between the interactive simulations using PhET tool and the real experience, considering acquiring and applying the cognitive skills as a key performance indicator. The experience has occurred with the adoption of a pre-test and post-test method. At the end of the session, we invited the simulation group learners to rate the sequence using a survey form. Obtained results have shown that PhET simulations have a remarkable effect on the acquisition and the application of new knowledge in Archimedes' thrust lesson; these effects are comparable with those of real experience. Moreover, the found results have shown a huge improvement in some other indicators like motivation, engagement and interaction inter-learners compared to the traditional method.
\end{abstract}

Keywords PhET Simulation, Archimedes Thrust, Understanding, Motivation, Interaction, Engagement, Physic

\section{Introduction}

During recent decades, information and communication technologies (ICT) have provided innovative tools; it is generally considered that their integration into teaching practices can improve students' learning capacity and teachers' potential. The simulations intended for learning in institutions, or in the context of distance learning are considered as the most promising tools in the experimental sciences teaching [1]. These educational applications can simulate real phenomena by creating models or virtual experiences, allowing learners to control variables and formulate hypotheses [2-4]. The use of computer simulations facilitate students' conceptual understanding [5,6], as well as improve its ability to predict the experiment results [7]. Additionally, they can positively influence the satisfaction, participation and initiative of pupils [8], as well as their perception of the classroom environment [9]. we also mention that the use of computer simulations in the teaching-learning process makes the students more interested in the course, and thus improves their academic results $[10,11]$. Another potential benefit of the interactive simulations is the improvement of the student's engagement [12] that can be used by the teachers to make their students' thinking visible. All these points of strength encourage us to use this technology in our experiments, to take benefit from their dynamic and interactive dimensions of teaching and learning.

In this research, a learning-teaching sequence has been performed using the PhET interactive simulation product. The purpose of this task is to compare the PhET impact on the learners' understanding with the experimental method, as well as its effect on students' motivation, inter-learner or learner-teacher interactions, and learner engagement with the traditional method. The choice of product used has been reinforced by an evaluation by inspection, respecting the Moroccan context. In our case, we decided to use the 
buoyancy product to simulate our results.

\section{Problematic}

In the traditional model of classroom, the teacher holds the knowledge. He explains, speaks and demonstrates for the majority part of the time, as well as assigning tasks and regulating learning. He is in phase advance compared to his learners because he is the only one to know the course of the session. According this model, the knowledge to be taught all passes through the teacher, and is transformed according to a typology of personal didactics transposition, in order to be assimilated by the learners. Using this methodology, the student doesn't contribute to the formulation of the knowledge, which negatively influences his understanding. With the competency-based approach adopted by Moroccan educational system since 2000, the learner becomes the center of the teaching-learning process. That's why the traditional pedagogical tools that make the teacher or the learning contents in the center of the teaching-learning process need to be reviewed again. Moreover, with the integration of the information and communication technology tools in the teaching and learning process, a new paradigm has immerged to completely change the relationships between the elements of the famous didactic triangle, in which the model based on the classical approach becomes no longer supported by learners who find themselves in a passive state when they have many digital resources [13]. In particular, this problem appears strongly in the physical sciences. Once the physical sciences are discussed, they generate the most negative attitudes according to [14]. So physics are only studied by brilliant students [15]. To handle this problem, an interactive multimedia is used to make students enjoyed and motivated to improve their learning capacity by making the activities more interesting, motivating and effective. In this context, we will answer through this study to the following questions: Does the pedagogical use of a PhET interactive simulation have a positive effect on the motivation and the engagement of learners? Can the PhET interactive simulations have a positive impact on the learners understanding?

\section{Presentation and Use of the Product in the Classroom}

\subsection{Product Presentation}

The digital product we used in our experience is an interactive simulation tool created by Wieman and his research team [16], as a part of the PhET (Physics Education Technology) project at Colorado Boulder University [17]. The PhET project aims to create and develop the interactive simulations to promote the learning of physical sciences. All the created simulations are freely available on the project web page. Since they use Flash or Java technology, they do not require installation and they work smoothly under major operating systems. The most innovative feature in the simulations presented in the PhET project gives the possibility to interact directly with the physical concepts and / or the virtual devices.

The simulation of the Buoyancy has been designed for the following goals:

- Check if an object sinks or floats when it is placed in a liquid, given that the density of the object and the liquid are known.

- Apply the density definition to both liquids and solids.

- Demonstrate the relation between the Archimedes' thrust and the weight of the displaced liquid.

- Describe how Archimedes' thrust is related to the relative density of an object in the fluid.

- Predict the weight of an object completely or partially immersed given its mass and volume.

- Describe the forces acting on a completely or partially immersed object.

- Explain how an object that is denser than water can be kept floating by placing it on an object less dense than water.

The tool animation window allows the user to edit the blocks and fluids properties. The directed arrows refer to the applied forces on the system.

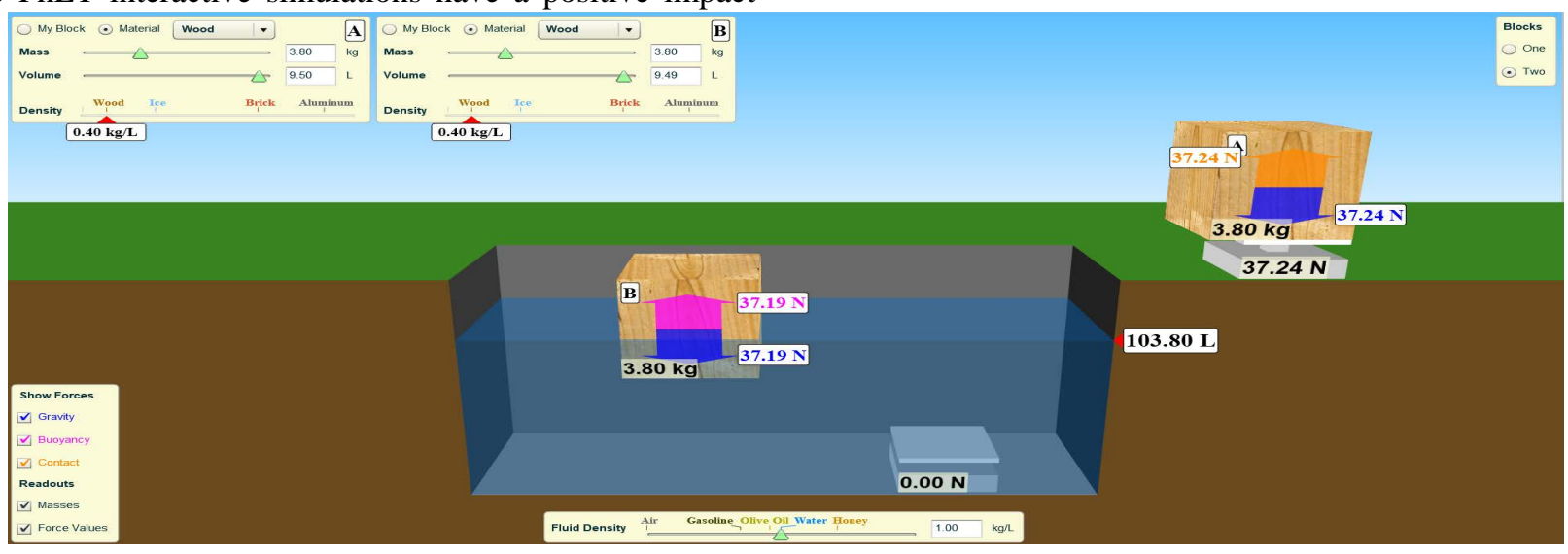

Figure 1. The animation window showing some options offered by the product 


\subsection{The Use of the Product in the Classroom}

We mentioned at the beginning of this article that the use of interactive simulation can improve student's learning, however, what students do with the simulation product and how they do it, are more important than the product itself, especially with the multiplicity of learning goals that the PhET product was designed for. Wieman, the creator of PhET simulations, mentions on the project web site that PhET can be used in many kinds of activities, but they are more effective with activities that use the guided survey to help students build their own understanding. In this context, we establish a pedagogical scenario in which the learner is called to take an active part in the learning process, by playing an important role in an interactive system [18]. That is to say, the learners are invited to directly simulate the activity shown in Table 1 , by choosing the form of the virtual experiments achieved during the session. Explicitly, these experiments are carried out in two stages: the first stage consists of a series of problems requiring reflection, and the second stage is composed of questions for which the learners can use the PhET tool to find the answer by manipulating the simulations.

The objectives of the activity are:

- Highlight the Archimedes' thrust.

- Demonstrate the relation between the Archimedes' thrust and the weight of the displaced liquid.

- Define the different parameters influencing the intensity of the Archimedes thrust.

Problem situation: Ahmed is in the swimming pool, suddenly, he feels lighter than what he feels at the outside. He claims that his weight under water is not the same as in the air. Is Ahmed right? How can we explain his "lightness" feeling? Will Ahmed have the same feeling in other liquids?

Table 1. Learner Activity list using PhET tool

Part A: Highlight the force applied by water to submerged solids.

Put a piece of wood in the Buoyancy Playground, try to sink it in the water, then release it.

- What do you observe?

- Comment your observation.

Part B: Compare the weight under water and in the air.

We model Ahmed by a solid brick having a cubic form and mass $18 \mathrm{~kg}$.

1. Using two dynamometers (outside and inside the buoyancy playground), how can you evaluate the force applied by the water on the solid?

2. What is the value of this force?

3. Is Ahmed right? How can you explain his "lightness" feeling?

Part C: Enunciate the Archimedes Principle

1. Put a piece of wood in the Buoyancy playground then check the two boxes «Buoyancy» and «Force values» in the animation window, next try to slowly sink the wood into the water. What do you observe? Are there any relationship between the submerged volume of the object, and the value of Archimedes' thrust? If so, how can it be determined using the PhET tool?

$$
\begin{aligned}
& \text { Note the volume } \mathrm{V}_{0} \text { of the water in the Buoyancy Playground, when it is empty. Next, put } \\
& \text { the piece of wood in the Buoyancy Playground and note again the new total volume } \mathrm{V}_{\mathrm{T}} \text {. } \\
& \text { - Calculate the weight of the volume of the displaced water. } \\
& \text { - Compare the value of the Archimedes thrust with the weight of the volume of displaced water and interpret the results. }
\end{aligned}
$$

2. Formulate the Archimedes principle.

Part D: Define the variables influencing the value of Archimedes thrust

1. What data can influence the value of Archimedes' force?

2. Using the PhET tool, check which of the following variables can influence the value of the Archimedes' thrust: The nature of the liquid (density) - The depth of immersion

- $\quad$ The mass of the object

- the volume of the object immersed. 


\section{Methodology}

\subsection{Research Design}

Our methodology consists of two main stages: the product inspection assessment stage, and the in-class experiment stage.

\subsubsection{Evaluation Phase}

Table 2. Consistency analysis of Evaluation Factors

\begin{tabular}{|c|c|c|}
\hline Criteria & Number of items & Cronbach's alpha \\
\hline The content & 5 & 0,85 \\
\hline Ergonomics & 4 & 0,84 \\
\hline Pedagogical use & 7 & 0,91 \\
\hline $\begin{array}{c}\text { Pedagogical } \\
\text { innovation }\end{array}$ & 4 & 0,89 \\
\hline
\end{tabular}

All the criteria have a good internal consistency $(\alpha>0.8)$, which justifies the validity of the grid.

Since one of the objectives of this work is to find out an effective alternative to traditional pedagogical tools, commonly used in the educational environment in Morocco, we have seen that the evaluation by inspection of the PhET tool before its use in class can be one of the pillars in this regard. What's more, a pedagogical multimedia is a didactic material to which a lot of importance should be given, from validating the objectives, the content, as well as the approach and everything related to their integration into pedagogical activities [19]. Indeed, a good understanding of the possible relationship between learning and multimedia requires an evaluation that focuses on the pedagogical effectiveness of multimedia, and on the achievement of the pedagogical objectives. This good understanding helps a lot in making decision on whether or not to use interactive multimedia in the educational process. For this reason, we used the evaluation grid that was developed and validated (Table 2) by Ahaji et al. [20]. The grid evaluates the multimedia product depending on the following criteria: the content, the ergonomics, the pedagogical use and the degree of pedagogical innovation. The evaluator rates each item from 0 to 5 based on its satisfaction. The evaluation team consists of an educational inspector of physic sciences in secondary school cycle, a specialist in science of teaching and 5 high school physics-chemistry teachers.

\subsubsection{Experiment}

In order to make the learner active in the process of learning, the teacher must use various teaching methods. The experimental method is defined as the statement of a problematic situation that gives the learner the opportunity to think and activate his knowledge to solve the problem, verify the hypotheses using the experiment, collect the results and give the conclusions. This method is the most used to teach the course of the Archimedes thrust, because the necessary didactic material are cheap and simple. In this part of study we compare two teaching sessions of Archimedes thrust, one using a real material and the other using an interactive simulation by means of PhET tool. This does not absolutely mean that we are trying to find an alternative to the use of real experience in the teaching and learning process, because we know the satisfactory potential provided by the real experimentation. We only want to highlight the potentials that interactive simulation technology can provide, so that the teacher can use it as an alternative in the absence of the possibility of realizing a real experience. Our study is carried out using the experimental pre-test and post-test methodology. The experimentation was carried out in a high school in the Rissani city (Morocco), using a sample of 44 students newly enrolled in the common science core; it was conducted using two groups representing two different classes from the same school during the 2019-2020 school year. The real experience group consists of 22 students, and the simulation group contains 22 students. At the end of the session, we invited the simulation group to rate the sequence using a survey form. The details of the study are given in the following table:

Table 3. Conducting of the Experiment

\begin{tabular}{|c|c|c|}
\hline PhET simulation group & Real experiment group & $\begin{array}{l}\text { Dedicate } \\
\text { d Time }\end{array}$ \\
\hline $\begin{array}{l}\text { In the multimedia classroom, we divide the students into } \\
\text { groups of three or four students per computer (the } \\
\text { multimedia room has } 7 \text { computers). We use a laptop to } \\
\text { accompany the students during the learning process. }\end{array}$ & $\begin{array}{l}\text { In the physics classroom, we divide the students into small groups ( } 3 \text { or } \\
4 \text { students in each group) and provide them with simple equipment, so } \\
\text { that everyone could feel what was going on. }\end{array}$ & \\
\hline \multicolumn{2}{|c|}{$\begin{array}{l}\text { Remind the equilibrium conditions of a solid under the action of two external forces (Weight and another force), on the density of the } \\
\text { material. }\end{array}$} & $15 \min$ \\
\hline \multicolumn{2}{|c|}{ Presentation of the problem situation. } & $10 \mathrm{~min}$ \\
\hline \multicolumn{2}{|c|}{ Collect and discuss the student hypothesis. } & $10 \mathrm{~min}$ \\
\hline $\begin{array}{l}\text { Verification of the students' hypothesis using the PhET } \\
\text { interactive simulation (the teaching learning activities). }\end{array}$ & Verification of the students' hypothesis using the real experience. & $60 \mathrm{~min}$ \\
\hline $\begin{array}{l}\text { Treatment of an applied exercise proposed by the learners } \\
\text { using the PhET product. }\end{array}$ & Resolve the applied exercise. & $20 \mathrm{~min}$ \\
\hline \multicolumn{2}{|r|}{ Post-test } & $25 \mathrm{~min}$ \\
\hline \multicolumn{3}{|c|}{ Gather the simulation group learners' appreciations related to the session by means of a survey form. } \\
\hline $\begin{array}{l}\text { The available material: A computer connected to the PhET } \\
\text { website; a technical data sheet containing the instructions; } \\
\text { and a worksheet to note the procedure, the results and } \\
\text { conclusions. }\end{array}$ & \multicolumn{2}{|c|}{$\begin{array}{l}\text { The available material: Dynamometer; Container, Water; a piece of wood; cubic } \\
\text { materials of different forms and masses; essence; a technical data sheet of the } \\
\text { experience; a worksheet to note the title, the experimental results and the conclusions. }\end{array}$} \\
\hline
\end{tabular}




\subsection{Tools Used to Gather Information}

\subsubsection{Pre-Test}

In order to define the reference before the formulation of the diagnostic test items, we determine the links between the part in question and the previous programs. On the collected database, we built a pre-test containing two exercises, aimed at assessing the degree of mastery of the pre-acquired.

\subsubsection{Post-Test}

The post-test is based on an evaluation model designed to test the comprehension and application competences that we have tried to develop in students through the integration ICT (Information and Communication Technology). The detailed formulation of the post-test is given in the appendix1. The post-test contains two exercises: the first one is a multi-choice questionnaire (MCQ); as for the second one, it is an application exercise consisting of two questions. The main purpose of the MCQ is to evaluate the following objectives:

- The ability to define the Archimedes' thrust.

- The ability to connect the intensity of Archimedes' thrust and the weight of the displaced liquid.

- The possibility to precisely determine the influencing factors on the intensity of Archimedes' thrust.

- The ability to make a match between the buoyancy of the object and the applied forces.

As for the second exercise, we aim to evaluate:

- The ability to apply the Archimedes' principle to calculate the value of the Archimedes' thrust.

- The ability to exploit the value of Archimedes' thrust.

Since the second exercise questions have structured answers, we have identified for each question a set of answer elements (Table 4), on which we base our assessment of the student proposed answers. For each element, a percent score (\%) has been specified, taking into account the program and the content of the learning-teaching sequence.

Table 4. The elements of answers and the rate of each of them from the question response

\begin{tabular}{|c|c|c|}
\hline $\mathrm{N}^{\circ}$ & Elements of answers & $\%$ \\
\hline \multirow{2}{*}{1} & Express the Archimedes principle. & 80 \\
\cline { 2 - 3 } & Give the numerical value with the unit. & 20 \\
\hline \multirow{3}{*}{2} & $\begin{array}{c}\text { Identify the forces applied to the object and give } \\
\text { the equilibrium conditions. }\end{array}$ & 40 \\
\cline { 2 - 3 } & $\begin{array}{c}\text { The correlation between the density of the object } \\
\text { and the value of the Archimedes thrust. }\end{array}$ & 35 \\
\cline { 2 - 3 } & $\begin{array}{c}\text { Give the numerical value of the density with the } \\
\text { unit. }\end{array}$ & 10 \\
\cline { 2 - 3 } & $\begin{array}{c}\text { Deduce the nature of the material of the studied } \\
\text { object based on the density value. }\end{array}$ & 15 \\
\hline
\end{tabular}

\subsubsection{Questionnaire}

In order to gather the appreciations and opinions of the simulation group learners, we have prepared a questionnaire; collected data focuses on the learner engagement, the motivation and the interactions between the learners, and between the teacher and the learner as well.

The students of the PhET group are invited to respond by "yes" or "no" to all the questions, except one open question, where they are asked to explain their impressions about the use of product. By using this method, we ensure more objectivity of the student's opinion than the oral interview, where the student is often biased towards the teacher [21].

\section{Results and Discussion}

\subsection{Product Evaluation}

After gathering data, we performed the descriptive analysis of the results; we calculated the mean and standard deviation of each criterion. Obtained results are given by the following table:

Table 5. The mean and the standard deviation of the results related to the inspection evaluation of PhET product

\begin{tabular}{|c|c|c|}
\hline Criteria & Mean & The standard deviation \\
\hline The content & 4,43 & 0,42 \\
\hline Ergonomics & 4,14 & 0,31 \\
\hline Pedagogical use & 4,24 & 0,21 \\
\hline Pedagogical innovation & 4,21 & 0,60 \\
\hline
\end{tabular}

All criteria have a mean score greater than 4 out of 5 . The mean obtained by all items was greater than or equal to 3.71 , starting from 3.71 to 4.86 . These results show clearly that the evaluation team is satisfied about the PhET product. In fact, these results are very consistent with the process of developing PhET simulations, basically, the PhET are the results of a long, complex and rigorous development process [22]. The PhET product is continuously fed with multiple researches related to physics teaching and pedagogical innovation.

\subsection{Students Performance in Tests}

\subsubsection{Pre-test Results}

For the pre-test exercises, the student gets the average when $50 \%$ of his answers are correct. The results are summarized in the following table:

Table 6. Percentage of students with a score greater than or equal to the average in each exercise

\begin{tabular}{|c|c|c|}
\cline { 2 - 3 } \multicolumn{1}{c|}{} & Exercise 1 & Exercise2 \\
\cline { 2 - 3 } \multicolumn{1}{c|}{} & $\%$ & $\%$ \\
\hline Experience group & 31,81 & 40,90 \\
\hline PhET group & 45,45 & 40,90 \\
\hline
\end{tabular}

According to Table 6, most of students (about $60 \%$ ) in both groups have obtained the scores less than the average 
in the both exercises. This is justified with the fact that most of students faced difficulties to mobilize mathematical equations of the density concept and equilibrium conditions of an object under two forces.

\subsubsection{Post-test Results}

The chart given below describes the results of the first exercise for the both groups. We note that these results express the percentage of the correct responses:

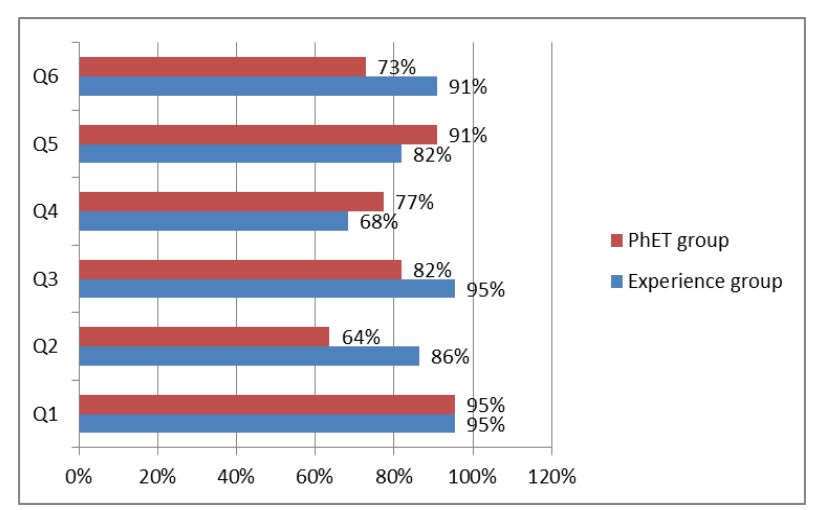

Figure 2. The rate of the correct answers of the first exercise for the both of groups

The graph above shows the satisfaction of the success rate of the both groups (the minimum of the good response rates is greater than 64\%). These results are interpreted with the fact that both of teaching-learning methodologies allow students to improve their cognitive competences.

The results of the both groups are identical in the question Q1, as for the questions Q2, Q3, Q6, the group of real experience outpaces the PhET simulation group, but in the questions Q4 and Q5, the PhET simulation group outpaces the real experience group. To verify the importance of the observed differences between students' performances in the groups, we used the chi-squared test. The test gives a chi-square value equal to 1.745455 , which means that the differences are not significant at a 95\% confidence level and 1 degree of liberty $(\mathrm{dl}=1, \alpha=0.05)$. Generally, the MCQ results indicate that using PhET simulation tool in the classroom has a considerable impact on the learner's capacity, especially to acquire new knowledge in the Archimedes thrust course. This effect is similar to the real experience one. This finding is explained by the fact that the simulation method offers to the learner, if needed, the ability to repeat the experience using new parameters as well as the ability to focus on the desired sequence, or to review each step and therefore progress at their own rhythm [23]. As a result, the PhET interactive simulation can be a good alternative to develop the acquisition of the cognitive competences for the students, in case of lack of real experience. Rebmann [21] also concluded that teaching Newtonian mechanics course using simulations helps student to acquire and develop new cognitive competencies.

In another comparison, the exercise 2 aims to compare the effect of the two methods on the degree of mastery of skills related to comprehension, these are mainly skills related to the application. Given the heterogeneity of the answers that characterize this type of question with constructed answers, we have stratified the scores obtained in the two questions as shown in Figure 3. The student gets the average mark in the question when $50 \%$ of his answers are correct.

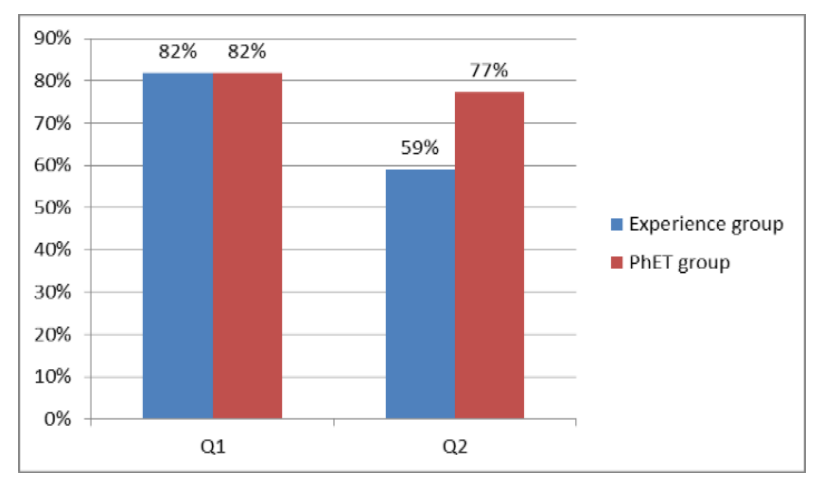

Figure 3. Percentage of students who have or exceed the average mark in each question

Figure 3 shows that both of the groups have the same rate $(82 \%)$ of students who scored or exceed the average mark in the first question Q1. However, the results of the second question Q2 show a variance of $18 \%$ for the benefit of the PhET group (77\%). These results consolidate the conclusions made in the previous comparison, related to the use of computer simulation in the Archimedes thrust course, to acquire and apply new knowledge. In addition, the results of the students reveal many improvements in the various difficulties encountered in the pre-test.

So, to explain these results, we adopted an analysis of the objective for each question, which allows us to extract the following conclusions:

- The first question Q1 aims to show how much the students can master the application of Archimedes' principle. The results of this assessment for both of the groups was very convincing, which makes PhET simulation very helpful for the majority of students to easily calculate the value of Archimedes thrust from the weight of the moved liquid. The PhET is an intuitive simulation tool, full of dynamic and interactivity, these properties help students to understand the studied principle; they show clearly the relationship between the liquid volume in the buoyancy playground, the submerged height of an object and the Archimedes' thrust value. In the same way, Orange [24] specifies that the simulations can be a real help for the teacher in order to achieve the learning objectives, while limiting the student's work to tasks directly related to the targeted learning.

- The objective of the second question Q2 is to exploit the value of the Archimedes' thrust to determine the nature of the material of the submerged object in 
water. To do so, the student should basically mobilize the cognitive resources of the equilibrium conditions of a solid under two forces, the Archimedes principle and the density definition, as well as the logic and calculus resources. In other words, this question aims to assess the learner's ability to make the link between the results of real or virtual experiences and theoretical reflection. And indeed, compared to the experimental activities, the PhET simulation can act as a cognitive bridge between theory and experience. From this point of view, Niedderer et al. [25] mention that if the usual experimental activities favor the equipment handling and the experimental measurements, the use of simulation favors the theoretical reflection.

Finally, this result confirms again the potential of the computer interactive simulations to facilitate the understanding of laws and principles of high school physics. The following is some related works and findings:

1) Prima et al. [26] confirm that PhET interactive simulation improves the understanding of solar system lesson.

2) Cahyani et al. [27] prove that the PhET simulation can successfully improve the students' ability to understand the concept of light refraction.

\subsection{Results of the Survey}

\subsubsection{Motivation Assessment}

Learner motivation is a major concern for researchers interested in learning process using interactive simulation. The concept of motivation is one of the premises of this movement, because of the strong relationship it has with learning [28]. The motivation like (subject) mentioned in [29] is a set of factors that push the learner to actively be engaged in the learning process, adopt attitudes and behaviors that may lead to the achievement of learning objectives, and to persevere while facing difficulties. In the same spirit, the motivation of the learner is an essential factor for the skills development [30-32]. Indeed, without interest, it is difficult to acquire new concepts, to make the link with the previous knowledge, and to persevere in the appropriation of new concepts.

According to the self-determination theory [33], the intrinsic motivation of the individual is determined by two main factors: the pleasure of an action and the interest it can provide. Starting from this psychological idea, we prepared the list of questions mentioned in the Table 7 to evaluate the learner's motivation, and to focus on the following points:

- Highlight the student's impression about the PhET tool;

- Compare PhET tool with traditional methods of learning and teaching;
- The possibilities of applying the PhET simulations in learning and understanding other physics courses;

Table 7. Questions list used to collect data to study learner's motivation

Comparing to the classical method, do you feel that this product helps you to better understand this course?

Comparing to the traditional method, do you find that this product has made the session more practical?

Do you think that this course would be better if it was explained using another technological tool?

Do you prefer to use interactive simulations more often in physics courses?

The analysis of the data gathered from the survey has demonstrated that students are quite motivated to learn using PhET interactive simulation. Most of the students enjoyed the Archimedes' thrust simulation using the PhET product. The following chart illustrates these results.

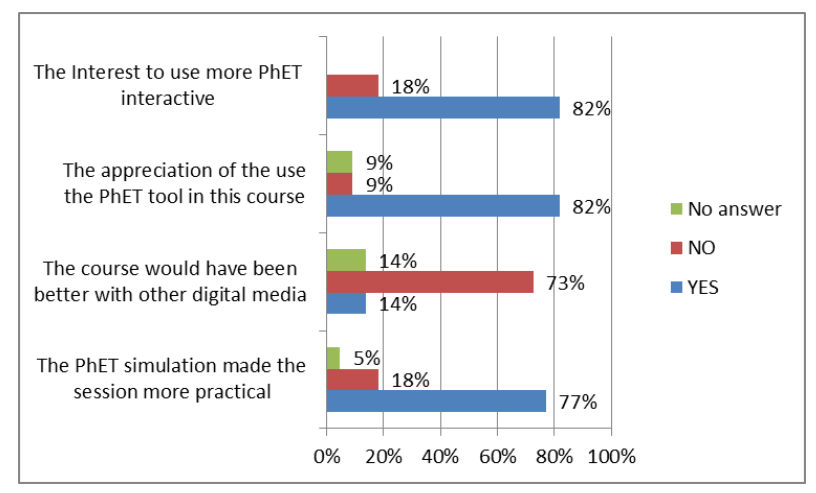

Figure 4. The motivation assessment to use interactive simulations PhET

In fact, $82 \%$ of learners enjoy using the PhET tool in this course, teaching using the PhET tool made the session more practical according to $77 \%$ of learners. $82 \%$ of learners prefer to use interactive PhET simulation frequently in the learning process. $73 \%$ are not interested in learning with another technology. These results confirm once again the motivation of learners to learn using PhET simulations [26], and the fact that students like to use PhET tools in the classroom [27]. In addition, the results confirm classroom observations and numerous related studies which have shown that the traditional method has no motivating effect on students [34].

Consequently, the computer interactive simulation is able to improve the pedagogical learning process thanks to its powerful resources, so it can generate the required motivation for the Moroccan learners.

\subsubsection{Engagement Assessment}

It is rarely that we read a research report about the impact of ICT on the learners' motivation without taking the engagement idea into account. Most of researches aimed at assessing the student engagement in the teaching sequence, are mainly based on self-regulation strategy, where the learner is responsible for his learning. The 
self-regulation is the learner's ability to control and modify his own cognitive activity, according to [35], and the self-regulation can be represented by three components: the objectives, the meta-knowledge and the strategies. An engaged learner is the one who exercises his cognitive learning process by anticipating, preparing, evaluating and adjusting his procedures according to the effects or the observed results [36]. Indeed, the motivated student is the one who translates his motivation into an engagement susceptive to promote his learning. According to some authors [37-39], the engagement can take one of the following dimensions: affective, cognitive or behavioral:

- Affective engagement: When a student finds pleasure in what he does, he asks himself whether the activities are useful or not.

- The cognitive engagement: refers to the conscious use and development of the appropriate learning strategies.

- The behavioral engagement: The student tends to be proactive, to explain the task to the other students; and to re-experiment if needed with new conditions, etc.

Starting from this context, we measure the engagement in our experience through the following questions:

1) Were your suggestions for solutions to the various problems raised by the activity multiple?

2) Did you use several strategies to solve the different problems identified in the activity?

3) Were you keen on stopping or repeating the experiment when you did not understand?

The results collected from these questions are as follows:

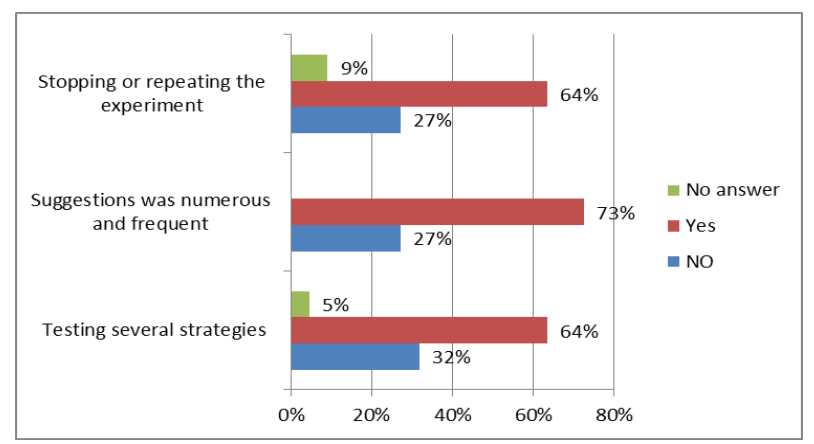

Figure 5. Student engagement statistics in the learning process

The statistics shown in Figure 5 confirm the positive effect of the PhET simulation on the student engagement in the learning process. In fact, $64 \%$ of learners confirm they have tried several strategies to solve the proposed problems; so many resources have been mobilized to calculate, resonate, apply and make analysis, which allows them to develop their methodology and their problem-solving skills. Thus, learning by means of PhET simulations make learners feel excited to reflect, so the learners can easily solve problems that can be faced in the learning process activities. As for the impact of the product on the learners' participation in the process of proposing solutions to the problems raised in the activity, 73\% confirm that their suggestions were multiple. This indicates that the learner feels its valuable partnership in the learning process, and its big responsibility against faced issues. The learners have right to the error. For this reason, their suggestions may fail to resolve the activity issues. But once the learner expresses his solution perception, he can confirm this suggestion or correct it, thus helping him to increase the confidence on his capabilities and improving his knowledge background. This process is rarely found in traditional methods where the learner is only a recipient. Moreover, the PhET simulation leads $64 \%$ of the learners to ask themselves if they have understood what happens, therefore, they stop the experience or repeat it if needed. Indeed, the simulation makes the learner active and allows him to do an instant feedback [40].

In summary, the course using the PhET interactive simulation is generally motivating and engaging; The learning process switched from one-way operation to cooperative process; And the learner becomes more active during the whole process,. This conclusion joins the idea that simulations are generally useful, engaging, and effective learning tools for students [41].

\subsubsection{Interaction Assessment}

In fact, the inter-learners interactions promote peer learning process and develop the learner's communication and argumentation skills, therefore, teaching and learning within the classroom aim at improving the effectiveness of this type of interactions, instead of teacher-learner interactions that are normally decreased. So, the interaction assessment is conducted using two important questions:

1) Being compared to the traditional method, does the use of PhET simulation contribute to increasing the interactions between you and your colleagues?

2) Being compared to the traditional method, does the use of the PhET simulation minimize your interactions with the teacher?

Data gathered from these two questions are organized and presented in the chart below; the first short look shows that the results are quite encouraging:

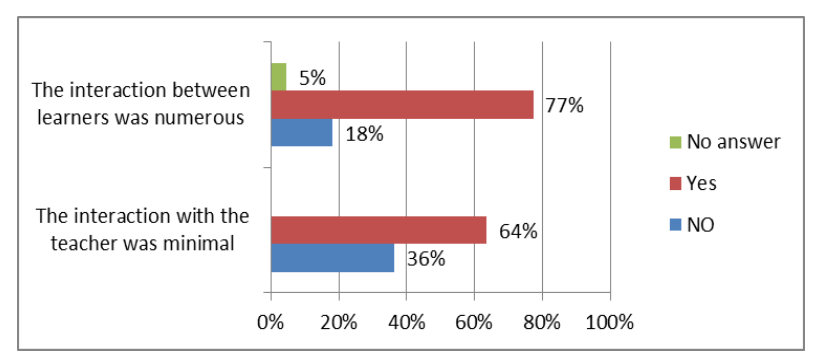

Figure 6. Learner-learner and teacher-learner interactions assessment 
The results presented in the figure 6 show that around $64 \%$ of the learners claim that using PhET simulation contribute to minimizing their interactions with the teacher. On the other hand, $77 \%$ of the learners have declared that the course was rich thanks to the exchange process between learners. Moreover, the use of this teaching tool helps learners to be integrated at the social learning environment. Thus, we can confirm that the adoption of simulations PhET improves the interactive exchange process between students. The peer interaction occurs in various modes, most of which are oral.

Generally, learners need a reason to interact with each other. In this sense, the use of interactive simulations in the classroom can be a good reason.

\subsubsection{Qualitative Results and Teacher Opinion}

In this part of the section, we collect data of 12 students who participated in the survey of the open-ended question. The purpose of this survey is to better understand the learners' perception related to the impact of the PhET product. Generally, students affirm the fluidity of knowledge transfer via interactive simulation technique, as well as the ease of understanding the demanded tasks during the learning process. In fact, most of the explained answers (some of the answers contain only admiration without explanation) are concentrated on the following properties: the ability to control variables and preview changes; the object modeling that is close to reality (color, shape, etc.); the clarity of the interface and the simplicity of its use; and the efficiency of carrying out the experiments and repeating them in a short time.

From a teacher's point of view, we observed a significant fluidity and reduction in the teaching tasks compared to the traditional method, since we are only solicited by the groups in some specific situations, thus our role becomes limited to supervise and animate the session.

This experiment also allows us to record a strong motivation of the students, as well as a high level of inter-learners' interactions to discuss the simulations, and to answer the exercise we have integrated in the sequence of the pedagogical scenario. The key of success of this experiment is the facilities provided by the simulations that help the learner to adopt the convenient learning rhythm, thus guaranteeing certain autonomy of learning [23].

\section{Conclusions}

In this paper, we demonstrate the encouraging impact of the PhET interactive simulation in the physics learning, especially for Moroccan high school level. We chose Archimedes' thrust as a target of study. We can basically elaborate the following conclusions:

- The performances of both the teaching methods (real experiment and with PhET simulation) have been persuading, particularly to acquire and apply the new knowledges related to the Archimedes' thrust course. Moreover, the gap between the methods was minimal, which makes the PhET simulation a real concurrent tool to the real experiment, with comparable results. This impressive impact highlights the importance of the interactive simulations to learn, study, and teach the complex and dynamic physical phenomena, especially when real experience is lacking, due to a shortage of materials and equipment in the school lab.

- Comparing to the classical method, the PhET interactive simulation improves the learning process. In other words, the use of PhET simulation in the "Archimedes' thrust" course motivates students during the session, increases inter-learners' interactions, and enhances learner engagement in the learning process.

Although the study does not allow us to formulate general results because of the short number of samples, it remains an important indicator of the benefits of integrating computer interactive simulations, especially PhET simulations, in the teaching of physics in Morocco. In order to consolidate our findings, and to make them more reliable, a large number of samples need to be used in the future works, also more experiments should be carried out using other interactive simulation tools to further discover more of their points of strength, as well as to determine the best ways to use these educational tools. 


\section{Appendix 1: Post-test Exercises}

Exercise 1

Check the box corresponding to the correct answer

1. The Archimedes' thrust is.

$\square$ A force acting horizontally from bottom up on an object in immersion within the fluid.

$\square$ A force acting horizontally from top down on an object in immersion within the fluid.

$\square$ A force acting vertically from bottom up on an object immersed in the fluid.

2. If i dipped my hand in the water...

$\square$ I am not subject to Archimedes' thrust

$\square$ My whole body subject to Archimedes' thrust

$\square$ My hand subject to Archimedes' thrust

3. In a liquid, the value of Archimedes' thrust applied to an immersed object is always equal to:

$\square$ Weight of moved liquid by the object.

$\square$ Weight of the submerged object.

$\square$ Weight of the liquid.

4. The value of Archimedes' thrust depends on...

$\square$ The depth of immersion and the form of the object.

$\square$ The volume of the object and the nature of the liquid.

$\square$ The mass of the object and the amount of liquid.

5. Given that an object floats on the surface of a liquid at rest, the intensities $\mathrm{W}$ and $\mathrm{F}$ of the weight $\vec{W}$ and the force $\vec{F}$ of Archimedes' thrust are such that
$\square \mathrm{W}<\mathrm{F}$.
$\square \mathrm{W}=\mathrm{F}$.
$\square \mathrm{W}>\mathrm{F}$.

6. Why would an overloaded ship float on the Dead Sea and not on the Mediterranean?

$\square$ Because the density of the Dead Sea is greater than that in the Mediterranean, the value of Archimedes force $F$ is greater and can hold the boat on the surface.

$\square$ Because the density of the Dead Sea is smaller than that in the Mediterranean, the value of Archimedes force $\mathrm{F}$ is greater and can hold the boat on the surface.

$\square$ Because the mass of the Dead Sea is greater than that in the Mediterranean, the value of the Archimedes force $\mathrm{F}$ is greater and can hold the boat on the surface.

Exercise 2

An object floats on the surface of the water (see figure aside).

Its dimensions are:

Height: $\mathrm{h}=0,2 \mathrm{~m}$; length: $\mathrm{L}=0,6 \mathrm{~m}$; width: $\mathrm{w}=0,2 \mathrm{~m}$

We give: $\rho_{\mathrm{w}}=1000 \mathrm{~kg} / \mathrm{m}^{3}, \mathrm{~g}=9,8 \mathrm{~N} / \mathrm{kg}$

1. The submerged height from the object is $0,08 \mathrm{~m}$. Calculate the intensity $\mathrm{F}$ of the Archimedes' thrust applied on the submerged part of the object.

2. Among the materials listed in the table below, determine the material that makes up this object.

$\begin{array}{ccccc}\text { Material } & \text { Polystyrene } & \text { wood } & \begin{array}{c}\text { Frozen } \\ \text { water }\end{array} & \begin{array}{c}\text { Aluminum } \\ \text { Density }\left(\mathrm{kg} / \mathrm{m}^{3}\right)\end{array} \\ & 10-15 & 300-500 & 920 & 2700\end{array}$




\section{REFERENCES}

[1] R. Bibeau, Les TIC à l'école : proposition de taxonomie et analyse des obstacles à leur intégration, EpiNet : Revue électronique de l'EPI, Paris, octobre 2005.

[2] S. M. Alessi, and S. R. Trollip, Computer-Based Instruction: Methods and Development. Englewood Cliffs, New Jersey: Prentice Hall, 1985.

[3] W. M. Roth, and A. Roychoudhury, The development of science process skill in authentic context. Journal of Research in Science Teaching, 30, p. 127-152, 1993.

[4] M. Droui, A. El Hajjami, M. Bouklah, \& S. Zouirech, Impact de l'apprentissage par problème sur la compréhension conceptuelle de la mécanique newtonienne. EpiNet: Revue électronique de l'EPI, 157, 2013.

[5] Jimoyiannis, A., \& Komis, V. (2001). Computer simulations in physics teaching and learning: a case study on students' understanding of trajectory motion. Computers \& Education, 36(2), 183-204.

[6] Zacharia, Z. C. (2007). Comparing and combining real and virtual experimentation: an effort to enhance students' conceptual understanding of electric circuits. Journal of Computer Assisted Learning, 23(2), 120-132.

[7] McKagan, S. B., Handley, W., Perkins, K. K., \& Wieman, C. E. (2009). A research-based curriculum for teaching the photoelectric effect. American Journal of Physics, 77(1), 87-94.

[8] Duran, M. J., Gallardo, S., Toral, S. L., Martinez-Torres, R., \& Barrero, F. J. (2007). A learning methodology using Matlab/Simulink for undergraduate electrical engineering courses attending to learner satisfaction outcomes. International Journal of Technology and Design Education, 17(1), 55-73.

[9] Kiboss, J. K., Ndirangu, M., \& Wekesa, E. W. (2004). Effectiveness of a computer-mediated simulations program in school biology on pupils' learning outcomes in cell theory. Journal of Science Education and Technology, 13(2), 207213.

[10] Limniou, M., Papadopoulos, N., Giannakoudakis, A., Roberts, D., \& Otto, O. (2007). The integration of a viscosity simulator in a chemistry laboratory. Chemistry Education Research and Practice, 8(2), 220-231.

[11] Baltzis, K. B., \& Koukias, K. D. (2009). using laboratory experiments and circuit simulation IT tools in an undergraduate course in analog electronics. Journal of Science Education and Technology, 18(6), 546-555.

[12] Adams, W. K., Reid, S., LeMaster, R., McKagan, S., Perkins K., Dubson, M., \& Wieman, C. E. (2008). A study of educational simulations Part I - Engagement and learning. Journal of Interactive Learning Research, 19(3), 397-419.

[13] Khenissi, M. A., Essalmi, F., and Jemni, M., 2014. Comparison between serious games and learning version of existing games. In Proceedings of the 6th World Conference on Educational Sciences. Online available from https://doi.org/10.1016/j.sbspro.2015.04.380
[14] Venturini, P. (2007). L'implication des élèves à apprendre la physique. Actes des 55e journées nationales de l'UdPPC (pp.1-10).

[15] Boyer, R. et Tiberghien, A. (1989). Opinion de professeurs et d'élèves sur l'enseignement des sciences physiques au lycée. Bulletin de l'Union des Physiciens, 712, 305-321.

[16] Wieman, C E. "A powerful tool for teaching science." Nature, 2006.

[17] Perkins, K., Moore, E., Podolefsky, N., Lancaster, K., \& Denison, C. (2012). Towards Research-based Strategies for Using PhET Simulations in Middle School Physical Science Classes. AIP Conference Proceedings, 1413, 295-298.

[18] P. M. Sadler, C. A. Whitney, L. Schore, F. Deutsch. Visualization and Representation of Physical Systems: Wavemaker as an Aid to Conceptualizing Wave Phenomena. Journal of Science Education and Technology, 8, p. 197-209, 1999.

[19] Bibeau, R. (1992). Protocole d'évaluation formative d'un logiciel éducatif, conception et réalisation. Direction des ressources didactiques et de la formation à distance. Québec.

[20] K. Ahaji, M.Droui, S. Zahim, B. Badda. Évaluation d'innovations en TIC et Expérimentation d'un logiciel d'Optique Géométrique. Journal of frantice, 9, 2014. http://www.frantice.net/docannexe/fichier/1084/10.pdf

[21] Rebmann, J. ; Joubert, R. et Desmond, Ph. (2000) : Intégration de simulation dans l'enseignement de la physique en première année de DEUG. Colloque enseignement et recherche en didactique des sciences (ERDS 2000), 1re éd., 2001, p. 15-26.

[22] W. K. Adams, S. Reid, R. LeMaster, S. B. McKagan, K. K. Perkins, M. Dubson et C. E. Wieman, A study of educational simulations part I - engagement and learning, Journal of Interactive Learning Research, 2008.

[23] El Hajjami, A.; El Mokri, A.; Ajana, L.; Chikhaoui, A. (2000). Approches analytiques de logiciels d'apprentissage des sciences physiques, Colloque Enseignement et Recherche en didactique des sciences «ERDS $2000 »$, p. 49-58.

[24] ORANGE C. (1992). Les logiciels de simulation : Substituts du réel ou véritables aides didactiques pour l'enseignement de la biologie-géologie ? In G.-L. Baron \& J. Baudé (Éd.). L'intégration de l'informatique dans l'enseignement et la formation des enseignants. Paris: INRP, p. $116-118$.

[25] Niedderer, H., Aufschnaiter, S., Tiberghien, A., Buty, C., Haller, K., Hucke, L., Sander, F. et Fischer, H. (2002). Talking physics in labwork contexts - A category based analysis of videotapes. In D. Psillos et H. Niedderer (Eds) Teaching and learning in the science laboratory (pp 31-40). Dordrecht: Kluwer.

[26] Prima, E., Putri, A., \& Rustaman, N. (2018). Learning solar system using PhET simulation to improve students' understanding and motivation. Journal of science learning; Vol 1, No 2 (2018): journal of science learning DO -10.2017/jsl.v1i2. 10239. 1. 10. 17509/jsl.v1i2. 10239.

[27] Cahyani, M. D., Firman, H., \& Rochintaniawati, D. (2013). The Effect of PhET Simulation Media on improvement Students' Achievement in the concept of Light Refraction. Bandung: Universitas Pendidikan Indonesia. 
[28] Westera, Wim. (2015). Games are motivating, aren't they? Disputing the arguments for digital game-based learning. International Journal of Serious Games. 8. https://doi.org/10. 17083/ijsg.v2i2.58.

[29] Zimmerman, B.J., et Martinez-Pons, M. (1992). Perceptions of efficacy and strategy use in the self-regulation of learning. Dans D.H. Schunk et J.L. Meece (Dir.): Student perception in the classroom (pp. 185-207). Hillsdale, NJ: Erlbaum.

[30] Audet, Lucie. 2009. " Mémoire sur le development de compétences pour l'apprentissage à distance: Points de vue des enseignants, tuteurs et apprenants ». Réseau d'enseignement francophone à distance du Canada.

[31] Forget, Pascal. 2015. « Les jeux sérieux au service de l'apprentissage ». In Le Tableau, vol.4, no 5. Gagnon-Mountzouris, Vicky. 2012. La techno-pédagogie au service de la formation: l'apprentissage par les jeux dans les bibliothèques.

[32] Rivard, Patrick. 2015. « Ludification: apprendre par plaisir et bien plus!».

[33] Ryan, R.M. et Deci, E.L. (2000). Self-determination theory and the facilitation of intrinsic motivation, social development, and well-being. The American Psychologist, $55,1,68-78$.

[34] Zheng, Yue. (2019). 3D Course Teaching Based on Educational Game Development Theory "Case Study of Game Design Course. International Journal of Emerging Technologies in Learning (iJET). 14.54. https://doi.org/10.3991/ijet.v14i02.9985

[35] NISBET, J., \& SHUCKSMITH, J. (1986). Learning Strategies. London: Routledge \& Kegan Paul.

[36] JEZEGOU A. (2013). The influence on the openness of an e-learning situation on adult students' self-regulation. International Review of Research on Open and Distance Learning, 14(2).

[37] Chapman, E. (2003). Assessing student engagement rates. College Park, MD: ERIC Clearinghouse on Assessment and Evaluation.

[38] Connell, J. P. (1990). Context, self, and action: A motivational analysis of self-system processes across the life span. In D. Cicchetti \& M. Beeghly (éds.), The self in transition: Infancy to childhood. (pp. 61-97). Chicago, IL: University of Chicago Press.

[39] Fredricks, J. A., Blumenfeld, P. C. \& Paris, A. H. (2004). School engagement: Potential of the concept, state of the evidence. Review of Educational Research 74(1), 59-109.

[40] M. Windschitl, T. Andre. Using computer simulations to enhance conceptual change: The roles of constructivist instruction and student epistemological beliefs. Journal of Research in Science Teaching, 35(2), p. 145-160, 1998.

[41] Perkins, K., Adams, W., Dubson, M., Finkelstein, N., Reid, S., \& Wieman, C. (2006). PhET: interactive simulations for teaching and learning physics. The Physics Teacher, 44(1), $18-23$. 